\title{
CHEMICAL COMPOSITION, ANTIMICROBIAL, AND ANTIOXIDANT ACTIVITIES OF TWO MOROCCAN THYMUS ESSENTIAL OILS
}

\author{
IMANE AOUAM*, YASSINE EL ATKI, AMAL TAROQ, FATIMA EL KAMARI, ABDELFATTAH ABDELLAOUI \\ Department of Biology, Laboratory of Physiology Pharmacology and Environmental Health, Faculty of Sciences Dhar El Mehraz, University \\ Sidi Mohamed Ben Abdellah, B.P. 1796, Atlas, Fez, Morocco. Email: imaneaouam@hotmail.com
}

Received: 24 October 2018, Revised and Accepted: 04 December 2018

\section{ABSTRACT}

Objective: The aim of the present study is to investigate chemical constituents of Thymus riatarum and Thymus blecherianus essential oils (EOs) as well as to evaluate, for the first time, their antioxidant effect and antibacterial activity against six bacterial strains responsible for nosocomial infections.

Methods: The chemical composition of EOs was analyzed using gas chromatography (GC) and GC-mass spectrometry, the antibacterial capacity of the two thymus species was evaluated against six bacteria species: Escherichia coli, Pseudomonas aeruginosa, Klebsiella pneumonia, Staphylococcus aureus, Acinetobacter baumannii, and Citrobacter sp. using disk diffusion method and microdilution assay. Finally, the antioxidant activity was measured by four different test systems of assay, namely free radical scavenging activities, ferric reducing/antioxidant power assays, total phenolic, and flavonoid contents.

Results: A total of 15 compounds representing $99.6 \%$ of T. riatarum oil were identified with thymol (28.8\%), borneol (20.0\%), and $\alpha$-phellandrene $(13.0 \%)$ as the main constituents. Eleven components of $T$. blecherianus were identified representing $98.2 \%$ of the total oil composition; the most abundant constituents were as follows: Carvacrol (45.9\%), bornyl acetate (20.1\%), and borneol (15.7\%). Strong antibacterial activity of the two EOs was identified against all bacterial strains tested. Concerning the antioxidant results, T. riatarum EO exhibited higher antioxidant activity than $T$. blecherianus in the three assays with an $\mathrm{IC}_{50}$ value equal to $5.75 \pm 0.06 \mathrm{mg} / \mathrm{ml}$, which was probably due to its high content of polyphenols $(28.95 \pm 0.13 \mathrm{mg} \mathrm{GAE} / \mathrm{g} \mathrm{DW})$. Total flavonoid content was found equal for the two EOs.

Conclusion: EO of T. riatarum and T. blecherianus from Morocco can be exploited as a natural antibacterial and antioxidant new potential sources.

Keywords: Thymus riatarum, Thymus blecherianus, Antibacterial activity, 2,2-Diphenyl-1-picrylhydrazyl, Ferric reducing/antioxidant power, polyphenol, Flavonoids.

(c) 2019 The Authors. Published by Innovare Academic Sciences Pvt Ltd. This is an open access article under the CC BY license (http://creativecommons. org/licenses/by/4. 0/) DOI: http://dx.doi.org/10.22159/ajpcr.2019.v12i1.30377

\section{INTRODUCTION}

Herbs and species are natural plant products which have been used for thousands of years for flavoring, food preservation, and as a source of traditional medicines [1]. Therefore, the demand of aromatic plants is increasing through the world for their content of phytochemicals that can alleviate illness, antimicrobial, and antioxidant [2-6]. Antioxidant effect of plant essential oils (EOs) has been used as food preservation, natural therapies, functional food to promote health, and reduce oxidative stress and has a major role in the treatment of many human chronic diseases related to degenerative disorders, cardiovascular, diabetes, cancer, arthritis, and cancer, by acting as free radical scavengers [7-9]. In the other hand, the resistance of antibiotic provokes an increasing interest in evaluating the antimicrobial effects of plant secondary metabolites against many pathogens, to identify and evaluate natural products to assure consumers a safe, wholesome, and nutritious food supply [10]

The genus Thymus (Family Lamiaceae) comprises about 215 species of herbaceous perennials and subshrubs [11]. While the Mediterranean region has been recognized as the center of this genus [13], twenty one species of thyme have been identified in Morocco, twelve are endemic [12]. Some of these species have been used for their preservative and medicinal properties [2] and have been added to foods (condiment and spice) [14] their EOs has found applications in cosmetic, such as toothpastes and deodorants [15]. Previous studies have demonstrated that Thymus species have strong insecticide, antioxidant, antibacterial, antifungal, antiviral, anti-inflammatory, and antispasmodic activity $[11,16,17]$. Different reports have shown that thymol and carvacrol are the main components of thymus EOs which are responsible for their high biological activities [18-21]. Among this genus, Thymus blecherianus and Riatarum locally called "zaatar" are the most important species from medicinal and aromatic properties and used worldwide for its antimicrobial activities.

To the best of our knowledge, there are no reports about antioxidant proprieties and antibacterial activity against bacteria responsible for nosocomial infections for the two thymus species (Blecherianus and Riatarum). Therefore, the objective of the present study is to investigate the chemical constituents of T. riatarum and T. blecherianus EOs as well as to evaluate, for the first time, their antioxidant and antibacterial activities.

\section{METHODS}

\section{Plant material}

Fresh leaves of T. blecherianus and T. riatarum were collected in Morocco at flowering stage (Mars 2016) from the region of Taza. They were identified by Professor Amina Bari, botanist Department of Biological Sciences, Faculty of Science, Sidi Mohammed Ben Abdellah University, Fez (Morocco). The leaves were dried for 7-10 days in the shade and then stored in cloth bags at $5^{\circ} \mathrm{C}$ until extraction.

\section{Preparation and analysis of EO}

Dried shoot was hydro-distilled for $3 \mathrm{~h}$ with $500 \mathrm{ml}$ of water using a Clevenger-type apparatus, according to the European 
Pharmacopoeia [22]. The EOs obtained were dried over anhydrous sodium sulfate and stored in a refrigerator at $4^{\circ} \mathrm{C}$ before analysis. The oil yield was based on dry weight of the simple.

\section{Gas chromatography-mass spectrometry analysis (GC-MS)}

The EOs compounds were analyzed on a Thermo Fischer capillary gas chromatograph directly coupled to a mass spectrometer system (model GC ULTRA S/N 20062969; Polaris QS/N 210729), HP-5MS nonpolar fused silica capillary column $(60 \mathrm{~m} \times 0.32 \mathrm{~mm}, 0.25 \mu \mathrm{m}$ film thickness $)$. The temperature was maintained at $40^{\circ} \mathrm{C}$ for $2 \mathrm{~min}$, then increased at a programmed rate of $2^{\circ} \mathrm{C}$ per min to a final temperature of $260^{\circ} \mathrm{C}$, which was maintained for $10 \mathrm{~min}$; injector temperature $250^{\circ} \mathrm{C}$. The helium was used as carrier gas at a flow rate of $1 \mathrm{ml}$ per min. Each sample was run in hexane with a dilution ratio of 10:100. Compounds were identified by matching their MS and retention index with those reported in literature [23]. The injected specimen volume was $1 \mu \mathrm{l}$ of diluted oil; split injection technique; ionization energy $70 \mathrm{eV}$ in the electronic ionization mode; ion source temperature $200^{\circ} \mathrm{C}$, scan mass range $\mathrm{m} / \mathrm{z} 40-650$; and interface line temperature $300^{\circ} \mathrm{C}$. The EO components were identified by comparing their retention times and mass fragmentations with NIST-MS and literature comparison [24].

\section{Bacterial strains}

Five Gram-negative bacteria (Escherichia coli, Klebsiella pneumoniae, Pseudomonas aeruginosa, Acinetobacter baumani, and Citrobacter sp.) and one Gram-positive bacteria (Staphylococcus aureus). These bacterial strains which are responsible for nosocomial infections were isolated in a hospital environment from clinical patients in reanimation service ( $\mathrm{CHU}$, Morocco).

\section{Antibacterial activity assessment}

The antibacterial power of T. riatarum and T. blecherianus EOs was determined using the agar disk diffusion procedure was adapted from a method used earlier [25]. Each microorganism stock was suspended in Mueller-Hinton (MH) broth and incubated at $37^{\circ} \mathrm{C}$ for $18-24 \mathrm{~h}$. The overnight cultures were diluted and adjusted to get a density of $1-5 \times 10^{6} \mathrm{CFU} / \mathrm{ml}(0.5 \mathrm{McF}$ arland turbidity standards). They were flood-inoculated onto the surface of $\mathrm{MH}$ agar plates and $6 \mathrm{~mm}$ diameter, sterile filter discs of Whatman paper $\mathrm{N}^{\circ} 3$, impregnated with $15 \mu \mathrm{g} /$ disc of the EO and were delivered onto the inoculated agar $\mathrm{MH}$. All plates were incubated for $18 \mathrm{~h}$ at $37^{\circ} \mathrm{C}$. Antibacterial effect was tested by measuring the zones of inhibition. The antibiotic standards used were imipenem, ampicillin, pristinamycin, and ceftriaxone [26-28]. The tests were carried out in triplicates.

\section{Determination of minimal inhibitory concentration}

The minimum inhibitory concentration (MIC) was performed using a microdilution assay in 96-well plates according to the experiment of the National Committee for Clinical Laboratory Standards [29] with some modification; the different concentrations of thymus EO are prepared in a suspension containing $0.2 \%$ agar in sterile distillate water to disperse the compounds without adding solvent or detergent [30]. They are carried out by successive dilutions $1 / 2$ ranging from 20 to $0.039 \mathrm{mg} / \mathrm{ml}$. The concentrations obtained in the well were between 5 and $0.0097 \mathrm{mg} / \mathrm{ml}$. The bacterial suspensions were prepared in the same manner described previously and diluted in $\mathrm{MH}$ broth and plated in 96 well plates at a density of $1-5 \times 10^{6} \mathrm{CFU} / \mathrm{ml}$. Thymus EO was added at different concentrations at the corresponding wells to determine MIC values. Finally, all plates were incubated at $37^{\circ} \mathrm{C}$ for $18-24 \mathrm{~h}$, bacterial growth was visually by adding to each well $20 \mu \mathrm{l}$ of 2,3,5-triphenyl tetrazolium chloride aqueous solution (1\%), with additional incubation for $1 \mathrm{~h}$. MIC was the lowest concentration that does not produce red color [31].

\section{Antioxidant activity}

\section{2,2-Diphenyl-1-picrylhydrazyl (DPPH) radical scavenging} activity

The DPPH test was introduced 50 years ago by Blois [32]. The ability of EOs to scavenge the DPPH radical was measured using the method described by Wu et al. [33]. $0.1 \mathrm{ml}$ of EOs or standard was added with $1.5 \mathrm{ml}$ of an ethanolic solution containing $0.1 \mathrm{mmol}$ of DPPH. After $30 \mathrm{~min}$ of incubation time at room temperature in the dark, the absorbance of the mixture was measured at $517 \mathrm{~nm}$ with a spectrophotometer (Jasco V-530). The inhibition percentage was calculated by the following equation:

I $(\%)=\left(1-\left(A_{s} / A_{0}\right)\right)^{*} 100$

Where $A_{0}$ and $A_{s}$ were the absorbances of the negative control and the sample, respectively. Butylated hydroxytoluene (BHT) served as positive control. The $\mathrm{IC}_{50}$ values were defined as the concentration of causing a $50 \%$ inhibition of DPPH radical.

\section{Reducing power capacity}

The reducing capacity of the tested EOs was determined in accordance with the procedure of Oyaizu [34]. $100 \mu \mathrm{l}$ of EO was mixed with $500 \mu \mathrm{l}$ of phosphate buffer $(0.2 \mathrm{M}, \mathrm{pH} 6.6)$ and $500 \mu \mathrm{l}$ of potassium ferricyanide $\left[\mathrm{K}_{3} \mathrm{Fe}(\mathrm{CN})_{6}\right] 1 \%$. The obtained solution was incubated for $20 \mathrm{~min}$ at $50^{\circ} \mathrm{C}$. The mixture was acidified with $500 \mu \mathrm{l}$ of trichloroacetic $10 \%$, which was then centrifuged for $10 \mathrm{~min}$ at $3000 \mathrm{rpm}$. The upper layer of the solution $(2.5 \mathrm{ml})$ was mixed with $500 \mu \mathrm{l}$ of distilled water, and $100 \mu \mathrm{l}$ of $\mathrm{FeCl}_{3}(0,1 \%)$ and the absorbance was measured at $700 \mathrm{~nm}$ (Jasco v-530). Quercetin was used as a standard. The results were expressed as $\mathrm{IC}_{50}(\mathrm{mg} / \mathrm{ml})$. $\mathrm{IC}_{50}$ (concentration corresponding 0.5 of absorbance) was calculated by plotting absorbance against the corresponding concentration.

\section{Total phenolic content (TPC)}

TPC of the volatile extracts was determined by the Folin-Ciocalteu method [35]. The $0.5 \mathrm{ml}$ of a known dilution of the E0 and $2 \mathrm{ml}$ of $7 \%$ sodium carbonate solution were added to $2.5 \mathrm{ml}$ of $10 \%$ (v/v) FolinCiocalteu reagent. The absorbance was read at $760 \mathrm{~nm}$ (Jasco v-530) after $2 \mathrm{H}$ of reaction at room temperature in the dark. Gallic acid was used as a standard for the construction of a calibration curve. Total phenols contents were expressed as milligrams of gallic acid equivalents per gram of EO (mg GAE/g EO)

\section{Total flavonoids contents (TFC)}

TFC of volatile extracts were measured by the aluminum chloride colorimetric assay [36]. $1 \mathrm{ml}$ of sample or rutin standard solution was added into a $10 \mathrm{ml}$ volumetric flask containing $4 \mathrm{ml}$ of distilled water. To the flask $0.30 \mathrm{ml} 5 \% \mathrm{NaNO}_{2}$ was added, after $5 \mathrm{~min}, 0.3 \mathrm{ml} 10 \% \mathrm{AlCl}_{3}$ was added to react for $6 \mathrm{~min}$. After that, $2 \mathrm{ml} \mathrm{NaOH}$ (1M) was added, and the total was made up to $10 \mathrm{ml}$ with distilled water. The solution was mixed, and absorbance was measured against the blank at $510 \mathrm{~nm}$ (Jasco v-530). Rutin was used as a standard for the construction of the calibration curve. TFC were expressed as milligrams of rutin equivalents per gram of EO (mg RE/g EO). All samples were analyzed in triplicate.

\section{RESULTS AND DISCUSSION}

\section{EOs composition}

The EO obtained from leaves of T. blecherianus and T. riatarum was yellow in color with a yield of $2 \%$ and $0.5 \%(\mathrm{v} / \mathrm{w})$, on dry weight basis, respectively. The obtained yield is higher then the results of studies of the same species with a yield of $1.75 \%$ and $0.26 \%$ for T. blecherianus and $T$. riatarum, respectively $[37,38]$

The analysis of two EOs was carried out using GC and GC-MS (Table 1). 15 compounds constitute $99.6 \%$ of the total T. riatarum EO. The main compounds identified were thymol (28.8\%), borneol (20.0\%), and $\alpha$-phellandrene (13\%). A different composition has been reported recently for the same species, with the main compounds were borneol (41.67\%), terpinene-4-ol (8.65\%), and trans-caryophyllene (7.59\%) [38]. Another study of this EO demonstrated that the major constituents were carvacrol $(22.3 \%)$, p-cymene $(17.5 \%)$, and $\alpha$-terpinene (10.3\%) [39]. Furthermore, Belmalha et al. revealed also the chemical composition of $T$. riatarum with 33 compounds identified (87.71\%); borneol (31.3\%) as the most abundant compound [40].

Regarding the EO compositions of T. blecherianus characterized by 11 compounds amounted to $98.2 \%$. The oil was dominated by carvacrol (45.9\%) followed by bornyl acetate (20.1\%) and borneol (15.7\%). 
Amarti et al. revealed a different chemical composition for the same species, which the main constituents are $\alpha$-terpinene $(42.20 \%)$ and thymol (23.90\%) [37]. The difference in the composition of EOs of the same species was attributed to various factors such as climate conditions, geographical location, harvesting period, and distillation method [41]

\section{Antibacterial activity}

The antibacterial effect of the EOs of T. blecherianus and T. riatarum was tested against six bacteria strains: E. coli; P. aeruginosa; K. pneumonia; S. aureus; A. baumannii, and Citrobacter sp. responsible for nosocomial infections in Center Hospital University of Fez Morocco.

The results from the antibacterial activity tested by diffusion in agar disc method are summarized in Table 2. All bacterial strains were susceptible to Thymus EOs studied. According to our results (Table 2), the two EOs were generally more effective against Gram-positive than Gram-negative bacteria; the higher antibacterial effect of EOs of T. blecherianus and T. riatarum was observed against $S$. aureus strain with $20.1 \pm 0.1 \mathrm{~mm}$ for $T$. blecherianus and $21 \pm 0.5 \mathrm{~mm}$ for T. riatarum. However, the lowest inhibition was showed against A. baumannii and Citrobacter sp. respectively. On the other hand, the antibacterial effect of two thymus EOs showed stronger activity when compared to all standard antibiotics used as positive controls except IMP.

The antibacterial activity evaluation using the microdilution method (Table 2) showed that T. blecherianus and T. riatarum EOs are efficient at various concentrations ranging from 0.019 to $0.156 \mathrm{mg} / \mathrm{ml}$. As presented in Table 2, the highest effective concentration was $0.019 \mathrm{mg} / \mathrm{ml}$ against S. aureus for two EOs and also against $K$. pneumonia for only T. riatarum.

Our results are highest than those reported by El Bouzidi et al. about the effective activity of wild and cultivated EO of T. maroccanus against

Table 1: Volatile compounds (\%) of EOs of studied Thymus spices

\begin{tabular}{llll}
\hline Component & RI & Tr (\%) & Tb (\%) \\
\hline a- thujene & 930 & 2.6 & 1.4 \\
$\alpha$-pinene & 943 & 7.3 & 0.9 \\
Camphene & 957 & 2.1 & 1.3 \\
$\alpha$-Phellandrene & 1003 & 13.0 & 0.6 \\
2-carene & 1007 & 0.8 & - \\
3-carene & 1020 & 1.2 & 3.1 \\
Borneol & 1170 & 20.0 & 15.7 \\
Bornyl acetate & 1289 & 4.9 & 20.1 \\
Thymol & 1297 & 28.8 & 5.0 \\
Carvacrol & 1305 & 2.3 & 45.9 \\
Acethyl thymol & 1357 & 4.6 & - \\
Eugenol & 1375 & 7.7 & 3.1 \\
Longifolene & 1403 & 1.1 & - \\
Caryophyllene & 1420 & 1.7 & 1.1 \\
Caryophyllene oxide & 1457 & 1.5 & - \\
Total & & 99.6 & 98.2 \\
\hline Rl Retention index, Tr: & &
\end{tabular}

RI: Retention index, Tr: Thymus riatarum, Tb: Thymus blecherianus, EOs: Essential oils
S. aureus with MIC $=0.46$ and $0.96 \mathrm{mg} / \mathrm{ml}$, respectively [17]. Rota et al. showed an increased sensitivity of $S$. aureus for the Thymol chemotype of Thymus zygis ssp. Gracilis [42]. However, Kaloustian et al. found that E. coli is more susceptible than S. aureus to Thyme [43]. Previous studies are also demonstrated that T. riatarum and T. numidicus EO exhibited a significant antibacterial activity which $S$. aureus showed higher inhibition $[38,44]$. This great antibacterial activity of thyme EO can be explained by the presence of carvacrol and thymol $[45,46]$, it is possible that other minor constituents are also contributing to the activity, as well as the synergistic impact of their combination in EO [47].

\section{Antioxidant activity}

\section{DPPH radical scavenging activity}

The antioxidant effect was often tested by the DPPH scavenging activity assay. Table 3 depicts DPPH results of T. blecherianus and riatarum EOs. As can be seen, T. riatarum had the greatest radical scavenging capacity with an $\mathrm{IC}_{50}$ value of $5.75 \pm 0.06 \mathrm{mg} / \mathrm{ml}$ followed by $T$. blecherianus $\left(\mathrm{IC}_{50}=6.87 \pm 0.3 \mathrm{mg} / \mathrm{ml}\right)$. However, when compared to the pure reference antioxidant BHT $(0.11 \pm 0.002 \mathrm{mg} / \mathrm{ml})$, all the tested EOs showed a significantly lower antioxidant activity $(\mathrm{p}<0.05)$. T. bleherianus EOs showed the lowest activity than that founded by Amarti et al. $\left(\mathrm{IC}_{50}=77.8 \mu \mathrm{g} / \mathrm{ml}\right)$ [48], and also lowest than T. serpyllum, Thymus algeriensis, and Thymus vulgaris with $\mathrm{IC}_{50}=0.96 \mu \mathrm{g} / \mathrm{ml}$, $\mathrm{IC}_{50}=1.64 \mu \mathrm{g} / \mathrm{ml}$, and $\mathrm{IC}_{50}=4.80 \mu \mathrm{g} / \mathrm{ml}$, respectively, reported by Nikolić et al. [49].

Recently, the demand for natural antioxidants for food conservation is one of the important trends in the food industry. Synthetic antioxidants such as BHT are toxic and carcinogenic [50]. This is why the use of EOs as natural antioxidants has attracted increasing interest in recent decades.

\section{Ferric reducing/antioxidant power (FRAP) capacity}

The reducing power capacity is a useful method for measuring antioxidant activities [51]. In this assay, hydroxyl radicals are generated by the reaction of $\mathrm{Fe}^{2+}$ and $\mathrm{H}_{2} \mathrm{O}_{2}$, and the antioxidant agents reduce the generation of hydroxyl radicals by chelating $\mathrm{Fe}^{2+}[52]$. The results of this activity (Table 3) showed that the EOs of the two plants have a comparable reducing capacity against the ferric ion; $14.73 \pm 0.25 \mathrm{mg} / \mathrm{ml}$ for T. blecherianus and $11.86 \pm 0.15 \mathrm{mg} / \mathrm{ml}$ for T. riatarum which is lowest than T. serpyllum and T. algeriensis $\mathrm{EO}\left(\mathrm{IC}_{50}=0.66 \mu \mathrm{g} / \mathrm{ml}\right.$ and $0.68 \mu \mathrm{g} / \mathrm{ml}$, respectively) [49] and lowest than wild and cultivated T. maroccanus with $\mathrm{IC}_{50}=139.31 \pm 1.08$ and $149.41 \pm 1.13 \mu \mathrm{g} / \mathrm{ml}$, respectively [17]. Tohidi et al. demonstrated that the reducing ability of the Thymus species was observed to increase with increasing E0 concentration [53]. Previous studies have also reported the antioxidant activity of EOs from different Thymus species [48,49]. The antioxidant activity of Thymus oils is often attributed to the presence of thymol, carvacrol, phenolic acids, and flavonoids [54].

\section{TPC and TFC}

It is generally demonstrated that the antioxidant activity of plant EOs is correlated with the TPC and TFC [51]. Therefore, to determine the antioxidant activity of T. blecherianus and Riatarum EOs, we analyzed the TPC and TFC of each test sample and results are presented in Table 4.

Table 2: Antimicrobial activity of Thymus blecherianus and Thymus riatarum EOs using disk diffusion assay and antibiotic standards

\begin{tabular}{|c|c|c|c|c|c|}
\hline \multirow[t]{2}{*}{ Bacterial species } & \multicolumn{2}{|c|}{$\begin{array}{l}\text { Thymus blecherianus EOs } \\
\text { (15 } \mathrm{\mu l} / \mathrm{disc})\end{array}$} & \multicolumn{2}{|c|}{$\begin{array}{l}\text { Thymus riatarum EOs } \\
\text { (15 } \mu \mathrm{l} / \mathrm{disc})\end{array}$} & \multirow{2}{*}{$\begin{array}{l}\text { Antibiotic standards } \\
\text { DD (mm) }\end{array}$} \\
\hline & DD (mm) & CMI (mg/ml) & DD (mm) & CMI (mg/ml) & \\
\hline Escherichia coli & $12 \pm 0.2$ & 0.156 & $15 \pm 0.8$ & 0.078 & 18 (IMP), 5 (AMP), 0 (CEC), 12 (PT) \\
\hline Klebsiella pпеитопiae & $14.3 \pm 0.8$ & 0.078 & $18 \pm 0.6$ & 0.019 & 30 (IMP), 0 (AMP), 12 (CEC), 10 (PT) \\
\hline Staphylococcus aureus & $20.1 \pm 0.1$ & 0.019 & $21 \pm 0.5$ & 0.019 & 39 (IMP), 0 (AMP), 10 (CEC), 16 (PT) \\
\hline Pseudomonas aeruginosa & $16 \pm 0.5$ & 0.078 & $17.6 \pm 0.8$ & 0.039 & 28 (IMP), 8 (AMP), 0 (CEC), 10 (PT) \\
\hline Acinetobacter baumannii & $10.6 \pm 0.7$ & 0.156 & $14.3 \pm 0.1$ & 0.078 & 22 (IMP), 0 (AMP), 5 (CEC), 6 (PT) \\
\hline Citrobacter sp. & $12 \pm 0.5$ & 0.078 & $15.5 \pm 0.9$ & 0.078 & 17 (IMP), 8 (AMP), 15 (CEC), 8 (PT) \\
\hline
\end{tabular}

MIC: Minimum inhibitory concentration, DD: Disk diffusion assay, diameter of inhibition zone including disk diameter of $6 \mathrm{~mm}$. ., EOs: Essential oils 
Table 3: DPPH radical scavenging activity and ferric reducing power capacity of different EO from Thymus blecherianus and Thymus riatarum

\begin{tabular}{lll}
\hline & $\begin{array}{l}\text { DPPH IC } \\
\text { (mg/ml) }\end{array}$ & $\begin{array}{l}\text { FRAP IC }_{\mathbf{5 0}} \\
\text { (mg/ml) }\end{array}$ \\
\hline Thymus blecherianus & $6.87 \pm 0.30^{\mathrm{a}}$ & $14.73 \pm 0.25^{\mathrm{a}}$ \\
Thymus riatarum & $5.75 \pm 0.06^{\mathrm{b}}$ & $11.86 \pm 0.15^{\mathrm{b}}$ \\
BHT & $0.11 \pm 0.002^{\mathrm{c}}$ & - \\
Quercetin & - & $0.03 \pm 0.006^{\mathrm{c}}$ \\
\hline
\end{tabular}

All the results were expressed as mean \pm SD of three different trials. In each line, values followed by different letters are significantly different $(\mathrm{p}<0.05)$ FRAP: Ferric reducing/antioxidant power, DPPH: 2,2-Diphenyl-1-picrylhydrazyl, BHT: Butylated hydroxytoluene, EOs: Essential oils

Table 4: Total phenolic and flavonoid contents of EO from Thymus riatarum and Thymus blecherianus

\begin{tabular}{lll}
\hline EO & TPC $(\mathbf{m g ~ G A E} / \mathbf{g})$ & TFC $(\mathbf{m g ~ R E} / \mathbf{g})$ \\
\hline Thymus blecherianus & $17.63 \pm 0.06^{\mathrm{a}}$ & $24.17 \pm 0.21^{\mathrm{a}}$ \\
Thymus riatarum & $28.95 \pm 0.13^{\mathrm{b}}$ & $24.20 \pm 0.23^{\mathrm{a}}$ \\
\hline
\end{tabular}

Data are reported as mean values \pm SD of three measurements. Means were significantly different when $\mathrm{p}<0.05$; values followed by different letters are significantly different, TPC: Total phenolic content, TFC: Total flavonoid content, EOs: Essential oils

TPC was determined in comparison with standard gallic acid, and the results were expressed in terms of $\mathrm{mg} \mathrm{GAE/g} \mathrm{of} \mathrm{sample.} \mathrm{As} \mathrm{we} \mathrm{can} \mathrm{see,}$ T. riatarum demonstrated the highest phenolic content $(28.95 \pm 0.13 \mathrm{mg}$ $\mathrm{GAE} / \mathrm{g}$ EO).

On the other hand, TFC results were expressed in terms of mg RE/g weight extract. As shown in Table 4, the total flavonoid content has been found equal for the two spices of thyme.

The results of total phenols in our study were found to be higher than the values reported in literature for Thymus species such as T. capitatus (15.06 $\pm 0.73 \mathrm{mg} \mathrm{GAE} / \mathrm{g}$ ) obtained by Jabri-Karoui et al. [55], T. vulgaris (8.55 mg QE/g) reported by Tohidi et al. [53], and T. daenensis subsp. Daenensis celak. ranged from 18.82 to 18.97 (mg GAE/g) obtained by Alizadeh et al. [56]. However, our total phenolic results are lowest than T. numidicus with $98.66 \pm 3.17 \mathrm{mg}$ EAG/g reported by Ali et al. [57] and T. satureioides $(69.05 \pm 0.01 \mathrm{mg} / \mathrm{g}$ GAE) reported by Wang et al. [58]. The observed antioxidant potential should be addressed to the phenolic oil constituents such as thymol and carvacrol [59].

Concerning TFC, T. capitatus showed a flavonoid content value of $10.62 \pm 0.24 \mathrm{mg} \mathrm{QE} / \mathrm{g}$ [55]. Baharfar et al. recorded that the flavonoid contents value of T. kotschyanus ranged from 32.04 to 74.60 $\mathrm{mgQE} / \mathrm{g}[60]$. It has reported that flavonoids have an interesting role in scavenging reactive oxygen species, which can counteract lipid oxidation in vitro and improve the body's antioxidant enzyme activity, and decrease peroxide formation in vivo [61].

\section{CONCLUSION}

Our study can be considered as the first report on the antibacterial effect against nosocomial bacteria species and antioxidant capacity basing on free radical scavenging activity (DPPH), FRAP, TPC, and TFC of T. riatarum and Blecherianus. The tested EOs demonstrated a strong antibacterial and antioxidant activities which are conferred by high thymol and/or carvacrol content. Thus, this study suggests the possibility of using the oils of these Thymus species as natural antioxidant and food preservatives, as well as pharmaceutical and natural therapies.

\section{ACKNOWLEDGMENTS}

The authors offer their sincere thanks to the Regional Center of Interface, University Sidi Mohamed Ben Abdellah, Fez, Morocco, for providing the $\mathrm{GC} / \mathrm{MS}$

\section{AUTHORS' CONTRIBUTIONS}

All the authors have contributed equally.

\section{CONFLICTS OF INTEREST}

The authors declare no conflicts of interest regarding the publication of this paper.

\section{REFERENCES}

1. Dong H, Zhang Q, Li L, Liu J, Shen L, Li H, Qin H. Antioxidant activity and chemical compositions of essential oil and ethanol extract of Chuanminshen violaceum. Ind Crop Prod 2015;76:290-7.

2. Saumya $\mathrm{S}$, Basha $\mathrm{P}$. In vitro evaluation of free radical scavenging activities of Panax ginseng and Lagerstroemia speciosa: A comparative analysis. Int J Pharm Pharm Sci 2010;3:165-9.

3. Prasanth NV, Dilip C, Dev KT, Augustine L, Saraswathi R. Evaluation of in-vitro cytotoxic and antioxidant activities of Ipomoea batatas. Int J Pharm Pharm Sci 2010;2:91-2.

4. Aharwal RP, Kumar S, Thakur Y, Deshmukh L, Sandhu SS. Evaluation of antibacterial activity of endophytic fungi Aspergillus japonicus isolated from Tridax procumbens L. Asian J Pharm Clin Res 2018;11:212.

5. Benyagoub E, Nabbou N, Razni D, Moghtet S. Antibacterial activity of 'Anastatica hierochuntica 1.' against some bacterial strains responsible for women's uro-genital infection, Asian J Pharm Clin Res 2018;11:222.

6. El-hagrassi AM, Abdallah WE, Osman AF, Abdelshafeek KA. Phytochemical study of bioactive constituents from Satureja montana 1. growing in Egypt and their antimicrobial and antioxidant activities. Asian J Pharm Clin Res 2018;11:142.

7. Srinivasan K. Role of spices beyond food flavoring: Nutraceuticals with multiple health effects. Food Rev Int 2005;21:167-88.

8. Valko M, Leibfritz D, Moncol J, Cronin MTD, Mazur M, Telser J. Free radicals and antioxidants in normal physiological functions and human disease. Int J Biochem Cell Biol 2007;39:44-84

9. Bajalan I, Rouzbahani R, Pirbalouti AG, Maggi F. Antioxidant and antibacterial activities of the essential oils obtained from seven Iranian populations of Rosmarinus officinalis. Ind Crops Prod 2017;107:305-11.

10. Bajpai VK, Al-Reza SM, Choi UK, Lee JH, Kang SC. Chemical composition, antibacterial and antioxidant activities of leaf essential oil and extracts of Metasequioa glyptostroboides miki ex hu. Food Chem Toxicol 2009; 47:1876-83.

11. Stahl-Biskup E, Sáez F. Thyme-the Genus Thyme. Vol. 15. London: CRC Press Book; 2002. p. 330

12. Benabid A. Evaluation et Préservation de la Biodiversité. Flore Ecosystèmes du Maroc, Paris: Ibis Press; 2015.

13. Ghasemi P, Barani M, Hamedi B, Ataei K, Karimi A. Environment effect on diversity in quality and quantity of essential oil of different wild populations of Kerman thyme. Genetika 2013;45:441-50

14. Zhang DY, Yao XH, Duan MH, Wei FY, Wu GH, Li L. Variation of essential oil content and antioxidant activity of Lonicera species in different sites of China. Ind Crops Prod 2015;77:772-9.

15. Costa P, Medronho B, Gonçalves S, Romano A. Cyclodextrins enhance the antioxidant activity of essential oils from three Lamiaceae species. Ind Crops Prod 2015;70:341-6.

16. Aouam I, Elatki Y, Taroq A, Elkamari F, Elyoussi B, Abdellaoui A. Chemical composition and antibacterial activity of the essential oil of Thymus citriodorus L. Growing wild in Morocco: Preventive approach against nosocomial infections. Int J Pharm Sci Rev Res 2018;51:72-5.

17. El Bouzidi L, Jamali CA, Bekkouche K, Hassani L, Wohlmuth $\mathrm{H}$, Leach D, Abbad A. Chemical composition, antioxidant and antimicrobial activities of essential oils obtained from wild and cultivated Moroccan thymus species. Ind Crops Prod 2013;43:450-6.

18. Moghimi R, Ghaderi L, Rafati H, Aliahmadi A, McClements DJ. Superior antibacterial activity of nanoemulsion of thymus daenensis essential oil against E. Coli. Food Chem 2016;194:410-5.

19. Ruiz-Navajas Y, Viuda-Martos M, Sendra E, Perez-Alvarez JA, Fernández-López J. Chemical characterization and antibacterial activity 
of Thymus moroderi and Thymus piperella essential oils, two Thymus endemic species from Southeast of Spain. Food Control 2012;27:294-9.

20. El Ouariachi EM, Hamdani I, Bouyanzer A, Hammouti B, Majidi L, Costa J, et al. Chemical composition and antioxidant activity of essential oils of Thymus broussonetii Boiss. and Thymus algeriensis Boiss. from Morocco. Asian Pac J Trop Dis 2014;4:281-6.

21. Russo M, Suraci F, Postorino S, Serra D, Roccotelli A, Agosteo GE. Essential oil chemical composition and antifungal effects on Sclerotium cepivorum of Thymus capitatus wild populations from Calabria, Southern Italy. Braz J Pharmacogn 2013;23:239-48.

22. Maisonneuve SA. European Pharmacopoeia. Vol. 3. France: SainteRuffine Counc; 1975. p. 68.

23. Joulain D, König WA. The Atlas of Spectral Data of Sesquiterpene Hydrocarbons. Hamburg: Verlag; 1998.

24. Adams RP. Identification of Essential oil Components by Gas Chromatography/Mass Spectorscopy. Carol Stream, IL: Allured Pub Corp; 2007.

25. Gary L, Furtado A. Single-disk diffusion testing (kirby-bauer) of susceptibility of Proteus mirabilis to chlorampheni-col: Significance of the intermediate category. J Clin Microbiol 1980;14:550-3.

26. Jalal Z, El Atki Y, Lyoussi B, Abdellaoui A. Phytochemistry of the essential oil of Melissa officinalis L. growing wild in Morocco: Preventive approach against nosocomial infections. Asian Pac J Trop Biomed 2015;5:458-61.

27. Mharti FZ, Lyoussi B, Abdellaoui A. Antibacterial activity of the essential oils of Pistacia lentiscus used in Moroccan folkloric medicine. Nat Prod Commun 2011;6:1505-6.

28. El Kamari F, Taroq A, El Atki Y, Aouam I, Lyoussi B, Abdellaoui A. Chemical Composition of essential oils from Vitex Agnus-Castus L. growing in Morocco and its in vitro antibacterial activity against clinical bacteria responsible for nosocomial infections. Asian J Pharm Clin Res 2018;11:365-8.

29. NCCLS (National Committee for Clinical Laboratory Standard). Performance Standards for Antimicrobial Susceptibility Testing. $9^{\text {th }}$ International Supplement; 1999.

30. Remmal A, Bouchikhi T, Rhayour K. Improved method for the determination of antimicrobial activity of essential oils in agar medium. J Essent Oil Res 1993;5:179-84.

31. Mello S, Luciano FB, Fronza N, Cunha A Jr., Scheuermann GN, Vieira CR. Chemical composition and antibacterial activity of Laurus nobilis essential oil towards foodborne pathogens and its application in fresh Tuscan sausage stored at 7 C. LWT Food Sci Technol 2014:59:86-93.

32. Blois MS. Antioxidant determinations by the use of a stable free radical. Nature 1958;181:1199-200.

33. Wu HC, Chen HM, Shiau CY. Free amino acids and peptides as related to antioxidant properties in protein hydrolysates of mackerel (Scomber austriasicus). Food Res Int 2003;36:949-57.

34. Oyaizu M. Studies on products of browning reaction antioxidative activities of products of browning reaction prepared from glucosamine. Jpn J Nutr 1986;44:307-16.

35. Slinkard VL. Total phenol analysis: Automation and comparison with manual methods. Am Soc Enologists 1977;28:49-55.

36. Zhishen J, Mengcheng T, Jianming W. The determination of flavonoid contents in mulberry and their scavenging effects on superoxide radicals. Food Chem 1999;64:555-9.

37. Amarti F, Satrani B, Aafi A, Ghanmi M, Farah A, Aberchane M, et al. Composition chimique et activité antimicrobienne des huiles essentielles de Thymus capitatus et de Thymus bleicherianus du Maroc. Phytotherapie 2008;6:342-7.

38. Fadli M, Bolla JM, Mezrioui NE, Pagès JM, Hassani L. First evidence of antibacterial and synergistic effects of Thymus riatarum essential oil with conventional antibiotics. Ind Crops Prod 2014;61:370-6.

39. Iglesias J, Vila R, Cañigueral S, Bellakhdar J, Idrissi A. Analysis of the essential oil of Thymus riatarum. J Essent Oil Res 1991;3:43-4.

40. Belmalha S, El Idrissi M, Echchgadda G, Amechrouq A, Bachir S. Chemical composition of the essential oils of three species of wild Thyme from Morocco: Thymus riatarum humbert et maire Thymus leptobotrys murb et Thymus munbyanus boiss. et reuter subsp. Ciliatus (DESF.) greuter et burdet. Phys Chem News 2012;63:122-8.
41. Argyropoulou C, Daferera D, Tarantilis PA, Fasseas C, Polissiou M. Chemical composition of the essential oil from leaves of Lippia citriodora H.B.K. (Verbenaceae) at two developmental stages. Biochem Syst Ecol 2007;35:831-7.

42. Rota MC, Herrera A, Martínez RM, Sotomayor JA, Jordán MJ. Antimicrobial activity and chemical composition of Thymus vulgaris, Thymus zygis and Thymus hyemalis essential oils. Food Control 2008;19:681-7.

43. Kaloustian J, Chevalier J, Mikail C, Martino M, Abou L, Vergnes MF. Étude de six huiles essentielles: Composition chimique et activité antibactérienne. Phytothérapie 2008;6:160-4.

44. Adrar N, Oukil N, Bedjou F. Antioxidant and antibacterial activities of Thymus numidicus and Salvia officinalis essential oils alone or in combination. Ind Crops Prod 2016;88:112-9.

45. El-Jalel LF, Elkady WM, Gonaid MH, El-Gareeb KA, Difference in chemical composition and antimicrobial activity of Thymus capitatus $\mathrm{L}$. essential oil at different altitudes. Futur J Pharm Sci 2018;4:156-160.

46. Hussain AI, Anwar F, Nigam PS, Sarker DS, Moore JE, Rao JR, et al. Antibacterial activity of some Lamiaceae essential oils using resazurin as an indicator of cell growth. LWT Food Sci Technol 2011;44:1199-206.

47. Pirbalouti AG, Hossayni I, Shirmardi HA. Essential oil variation, antioxidant and antibacterial activity of mountain fennel (Zaravschanica membranacea (Boiss.) M. Pimen.). Ind Crops Prod 2013;50:443-8.

48. Amarti F, Satrani B, Ghanmi M, Aafi A, Farah A, Aarab L, et al. Activité antioxydante et composition chimique des huiles essentielles de quatre espèces de thym du Maroc. Acta Bot Gall 2001;158:513-23.

49. Nikolić M, Glamočlija J, Ferreira CF, Calhelha RC, Fernandes A, Marković T, et al. Chemical composition, antimicrobial, antioxidant and antitumor activity of Thymus serpyllum L., Thymus algeriensis Boiss. And reut and Thymus vulgaris L. essential oils. Ind Crops Prod 2014;52:183-90.

50. Safer AM, al-Nughamish AJ. Hepatotoxicity induced by the antioxidant food additive, butylated hydroxytoluene (BHT), in rats: An electron microscopical study. Histol Histopathol 1999;14:391-406.

51. Hyun TK, Kim HC, Kim JS. Antioxidant and antidiabetic activity of Thymus quinquecostatus Celak. Ind Crops Prod 2014;52:611-6.

52. Bokhari J, Khan MR, Shabbir M, Rashid U, Jan S, Zai JA, et al. Evaluation of diverse antioxidant activities of galium aparine. Spectrochim Acta A Mol Biomol Spectrosc 2013;102:24-9.

53. Tohidi B, Rahimmalek M, Arzani A. Essential oil composition, total phenolic, flavonoid contents, and antioxidant activity of Thymus species collected from different regions of iran. Food Chem 2017;220:153-61.

54. Nickavar B, Esbati N. Evaluation of the antioxidant capacity and phenolic content of three Thymus species. J Acupunct Meridian Stud 2012;5:119-25.

55. Jabri-Karoui I, Bettaieb I, Msaada K, Hammami M, Marzouk B. Research on the phenolic compounds and antioxidant activities of Tunisian Thymus capitatus. J Funct Foods 2012;4:661-9.

56. Alizadeh A, Alizadeh O, Amari G, Zare M. Essential oil composition, total phenolic content, antioxidant activity and antifungal properties of Iranian Thymus daenensis subsp. daenensis celak. As in influenced by ontogenetical variation. J Essent Oil Bearing Plants 2013;16:59-70.

57. Ali IB, Bahri R, Chaouachi M, Boussaïd M, Harzallah-Skhiri F. Phenolic content, antioxidant and allelopathic activities of various extracts of Thymus numidicus Poir. Organs. Ind Crops Prod 2014;62:188-95.

58. Wang HF, Yih $\mathrm{KH}$, Yang $\mathrm{CH}$, Huang KF. Anti-oxidant activity and major chemical component analyses of twenty-six commercially available essential oils. J Food Drug Anal 2017;25:881-9.

59. Hazzit M, Baaliouamer A, Veríssimo AR, Faleiro ML, Miguel MG. Chemical composition and biological activities of Algerian Thymus oils. Food Chem 2009;116:714-21.

60. Baharfar R, Azimi R, Mohseni M. Antioxidant and antibacterial activity of flavonoid-, polyphenol- and anthocyanin-rich extracts from Thymus kotschyanus boiss and amp; hohen aerial parts. J Food Sci Technol 2015;52:6777-83.

61. Nakao K, Murata K, Itoh K, Hanamoto Y, Masuda M, Moriyama K, et al. Anti-hyperuricemia effects of extracts of immature Citrus unshiu fruit. J Tradit Med 2011;28:10-5. 